2 Superoxide and nitrous acid production from nitrate photolysis is enhanced by

7 France.

8 Department of Chemistry, Indiana University, 800 East Kirkwood Avenue, Bloomington,

9 Indiana 47405, United States.

10 \$School of Public and Environmental Affairs, Indiana University, 1315 East 10th Street,

11 Bloomington, Indiana 47405, United States

12 *To whom correspondence should be addressed. Email: christian.george@,ircelyon.univ-lyon1.fr,

13 jdraff@indiana.edu

$14 \quad$ "These authors contributed equally to this work

\title{
15 Contents:
}

16 Pages S1 to S29

17 Supplementary Information text

18 Section $\mathrm{S} 1$ to $\mathrm{S} 8$

19 Figs. S1 to S8

20 Tables S1 to S4

21 Supplementary References 


\section{S1. Materials}

The DAOM surrogates used here were nonanoic acid, 1-octanol, acetic acid, propionic acid,

25 valeric acid, and ethanol. Acetic acid (VWR, 100\%), acetone (Sigma Aldrich, $\geq 99.5 \%$ ), 26 diethylenetriaminepentaacetic acid (DTPA, Sigma Aldrich, $\geq 99 \%$ ), ethanol (Sigma Aldrich, $\geq$ 27 99.8\%), hydrochloric acid ( $\mathrm{HCl}$, Sigma Aldrich, ACS reagent, 37\%), methyl cypridina luciferin 28 analog (MCLA, Sigma Aldrich, $\geq 98.0 \%$ ), nitrite standard solution (Titrisol, $1000 \mathrm{mg} \mathrm{L}^{-1} \mathrm{NO}_{2}^{-}$in 29 water), sodium nitrite $\left(\mathrm{NaNO}_{2}\right.$, Sigma Aldrich, $\left.\geq 99 \%\right)$, nonanoic acid (NNA, Sigma Aldrich, 30 99.5\%), n-(1-naphthyl)-ethylenediamine dihydrochloride (Sigma Aldrich, $\geq 98.0 \%$ ), potassium 31 phosphate monobasic (Sigma Aldrich, $\geq 99 \%$ ), propionic acid (Fluka, $\geq 99.5 \%$ ), sulfanilamide 32 (Sigma Aldrich, $\geq 98.0 \%$ ), superoxide dismutase (SOD, Sigma Aldrich, from bovine erythrocytes), 33 valeric acid (Alfa Aesar, 99\%), 1-octanol (Sigma Aldrich, 99\%), sodium nitrate (Sigma Aldrich, $\geq$ $3499.0 \%$ ), sodium hydroxide (Sigma Aldrich, 35 wt.-\% solution in water), and sulfuric acid (Sigma 35 Aldrich, $\geq 95 \%$ ) were used without further purification. All solutions were freshly prepared using 36 ultrapure water (Elga Purelab Classic or Milli-Q Reference, $18.2 \mathrm{M} \Omega \mathrm{cm}$ ). Superoxide stock 37 solutions were produced photochemically (see section S1) with solutions made of 1.0 M ethanol, $3850 \mu \mathrm{M}$ DTPA, and $41 \mathrm{mM}$ acetone, adjusted to $\mathrm{pH} 12$. DTPA is a chelating agent added to 39 minimize superoxide production from transition metal impurities. Chemiluminescence reagent 40 solutions were made with $5 \mu \mathrm{M}$ MCLA, $50 \mathrm{mM}$ phosphate buffer, and $50 \mu \mathrm{M}$ DTPA, adjusted to $41 \mathrm{pH}$ 6. Solutions used for superoxide quantitation were prepared under conditions that exclude trace 42 metals, which are known interferences. ${ }^{1}$ Our $\mathrm{NaNO}_{3}$ stock did not contain any organic impurities, 43 as verified by GC-MS.

Concentrations for 1-octanol and nonanoic acid were chosen to be $1 \mathrm{mM}$, based on what is 45 required to form an organic microlayer at the solution-air interface. A nitrate concentration of 10 
$46 \mathrm{mM}$ was chosen in order to simulate concentrations observed in the aerosol condensed phase and

47 on desiccated environmental surfaces. Concentrations of acetic acid, acetone, ethanol, propionic 48 acid, and valeric acid were set to $1 \mathrm{mM}$ for proper comparison with the semi-soluble organics. To

49 determine background chemiluminescence, superoxide dismutase was added at $50 \mathrm{kU} \mathrm{L}^{-1}$ as

50 suggested by Rose et al. ${ }^{1} \mathrm{~A} \mathrm{pH}$ of 6 was chosen in order to simulate the $\mathrm{pH}$ of some atmospheric

51 condensed phases as well as many freshwater environments. In addition, this $\mathrm{pH}$ also allowed us

52 to observe outgassing of $\mathrm{HONO}_{(\mathrm{g})}$ from nitrate solutions and to register differences between

53 photoproduct yields between solutions containing the various DAOM surrogates. As demonstrated

54 in Figure $\mathrm{S} 3 \mathrm{~B}$, nitrate solutions with higher $\mathrm{pH}$ show significantly less $\mathrm{HONO}_{(\mathrm{g})}$ emitted since at

55 this $\mathrm{pH}$ range $\mathrm{NO}_{2}^{-}$(aq) is the dominant $\mathrm{N}(\mathrm{III})$ species formed.

\section{S2. Details of $\mathrm{NO}_{\mathrm{X}}$ and HONO Measurements}

Figure $\mathrm{S} 1 \mathrm{~A}$ shows the schematic for $\mathrm{NO}_{2(\mathrm{~g})}$ and $\mathrm{HONO}_{(\mathrm{g})}$ production measurements made used to irradiate a $14 \mathrm{~mL}$ cylindrical quartz cell, half-filled with $7 \mathrm{~mL}$ of phosphate buffered $(25$ $\mathrm{mM})$ nitrate solutions $(10 \mathrm{mM})$ with or without DAOM surrogates $(1 \mathrm{mM})$ under static conditions.

61 Solution $\mathrm{pH}$ for all experiments was kept to 6.0, which falls within the range of found in many

62 environmental aqueous systems. The DAOM surrogates used here were nonanoic acid, 1-octanol,

63 acetic acid, propionic acid, valeric acid, and ethanol. Details of all chemicals used and an

64 explanation for the choice of organic concentrations in this study are provided in Section S1. The

65 reactor headspace was continuously purged with $300 \mathrm{sccm}$ pure air, causing a residence time of

66 only $1.4 \mathrm{~s}$ which minimized gaseous photochemistry; $\mathrm{NO}_{2(\mathrm{~g})}$ in the outflow was measured within

$672.1 \mathrm{~s}$ using a commercial chemiluminescence analyzer (CLD $88 \mathrm{CY}$ p) while $\mathrm{HONO}_{(\mathrm{g})}$ was 68 measured within $1.1 \mathrm{~s}$ by a long path absorption photometer instrument (QUMA, Model LOPAP- 
69 03). The $\mathrm{NO}_{2(\mathrm{~g})}$ concentration was corrected by subtracting HONO concentration. We note that

70 with a flow rate of $300 \mathrm{sccm}$ and a reactor headspace volume of $7 \mathrm{~cm}^{3}$, the residence time would

71 only be $1.4 \mathrm{~s}$. Assuming a HONO photolysis rate of $5 \times 10^{-3} \mathrm{~s}^{-1}$ for our lamp, we expect $0.7 \%$ of

72 emitted HONO in the photochemical cell is photolyzed. This would have a minimal affect to

73 observed $\mathrm{HONO}$ and $\mathrm{NO}_{\mathrm{x}}$ yields.

The LOPAP is an in situ measurement device which absorbs gaseous HONO with a stable

75 solution of $0.06 \mathrm{M}$ sulfanilamide and $1.2 \mathrm{M} \mathrm{HCl}$ in an external sampling unit. $\mathrm{HONO}_{(\mathrm{aq})}$ is then

76 detected photo-metrically in a long-path absorption Teflon AF tube after the sulfanilamide

77 diazonium salt is converted into an azo dye though reaction with $0.4 \mathrm{mM} n$-(1-naphthyl)-

78 ethylenediamine dihydrochloride solution. A detailed description of LOPAP instrument can be

79 found elsewhere. ${ }^{2}$ The sampling stripping coil was kept a constant temperature of $15^{\circ} \mathrm{C}$ and consists

80 of two channels: channel 1 uptakes $\mathrm{HONO}_{(\mathrm{g})}$ and a small fraction of interfering species, while the

81 known interfering species are taken up by channel $2 .{ }^{3} \mathrm{HONO}_{(\mathrm{g})}$ concentrations are obtained though

82 subtracting the calibrated signal of channel 2 from channel 1 . The LOPAP was calibrated by a

83 known concentration of $\mathrm{NO}_{2}{ }^{-}$(Titrisol) solution every 4 days. The gas and liquid flow rates were

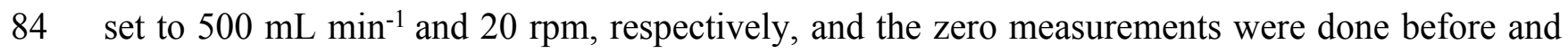

85 after each experiment. With these settings, the detection limit and accuracy of the instrument are

86 around 5 ppt and 10\% (+ detection limit), respectively, and the sampling efficiency of HONO is

87 close to $100 \%$.

88 S3. Quantitation of $\mathrm{O}_{2}^{-} / \mathrm{HO}_{2(\mathrm{aq})}$ during Photochemical Experiments

89 Figure S1B depicts the system used to measure $\mathrm{O}_{2}^{-}$(aq) produced when aqueous solutions 90 containing nitrate and/or organics were irradiated with UV-visible light. Stirred phosphate-buffered 
$91(5 \mathrm{mM})$ nitrate $(10 \mathrm{mM})$ solutions with or without DAOM surrogates were irradiated by a $\mathrm{Hg}-\mathrm{Xe}$

92 arc lamp (Spectra Physics, Oriel $200 \mathrm{~W}$, photon flux $=1.1 \times 10^{19}$ photons $\mathrm{cm}^{-2} \mathrm{~s}^{-1}$ ) with a dichroic

93 mirror and a glass filter to remove IR and UV wavelengths $(\lambda<295 \mathrm{~nm})$, respectively. Photon flux

94 of the lamp was determined by 2-nitrobenzaldehyde actinometry (Figure S2). ${ }^{4}$ The lamp was

95 allowed to warm up for at least $60 \mathrm{~min}$ before initiating experiments to prevent large deviations in

96 photon flux between experiments. Nitrate solutions were sampled continuously at a rate of $2.3 \mathrm{~mL}$

$97 \mathrm{~min}^{-1}$ and irradiated for $25 \mathrm{~min}$. Following photolysis, solutions were protected from light for 5

98 min and then $10 \mathrm{kU}$ of superoxide dismutase (SOD) was added to scavenge all remaining

99 superoxide and reveal background chemiluminescence due to MCLA autoxidation. Detection 100 limits were consistently below $100 \mathrm{pM}$.

Measured superoxide concentrations were corrected for decay within the sample line by measuring the apparent 1 st order decay rate after extinguishing the light. A factor was then applied

103 with equation $\mathrm{S} 1$, which is a rearrangement of the first-order integrated rate law,

$$
\left[\mathrm{O}_{2}^{-}\right]_{0}=\left[\mathrm{O}_{2}^{-}\right]_{\mathrm{t}} \times \mathrm{e}^{k t}
$$

105 where $\left[\mathrm{O}_{2}^{-}\right]_{0}$ is the original concentration in the reactor, $\left[\mathrm{O}_{2}{ }^{-}\right]_{\mathrm{t}}$ is concentration of superoxide

106 detected after transit time $t$ between reactor and detector, and $k$ is the rate constant for first order 107 decay. The sample transit time only changed if the sample line was replaced due to either 108 instrument maintenance or experimental constraints.

109 S4. Calibration of the Flow Injection Chemiluminescence (FIC) Analyzer

110 Superoxide is photochemically produced by a well-established method to calibrate the FIC 111 analyzer (see Figure S8). ${ }^{5}$ High $\mathrm{pH}$ solutions of ethanol, acetone, and DTPA are irradiated with 
$112254 \mathrm{~nm}$ light while continuously stirred in a quartz cuvette. Stock superoxide concentrations are

113 determined spectrophotometrically by UV-visible spectroscopy. A kinetic model was used to

114 deconvolute the $\mathrm{O}_{2}^{-}$(aq) absorbance from that of $\mathrm{H}_{2} \mathrm{O}_{2(\text { aq) }}$ and $\mathrm{HO}_{2}^{-}$(aq) formed during the second

115 order disproportionation of superoxide. ${ }^{5}$

116 A $200 \mu \mathrm{L}$ aliquot of stock $\mathrm{O}_{2}^{-}$is diluted in $10 \mathrm{~mL}$ of $\mathrm{pH} 12,50 \mu \mathrm{M}$ DTPA to produce a

117 secondary stock concentration of $\sim 1.5 \mu \mathrm{M} \mathrm{O}_{2}^{-}$. This 10 -fold dilution decreases the decay rate $\left(k_{\mathrm{obs}}\right)$

118 by two orders of magnitude, and the secondary stock $\mathrm{O}_{2}{ }^{-}$concentration is calculated for the

119 remainder of the experiment. Bielski et al. ${ }^{6}$ determined an equation (Eq. S2) that predicts $k_{\text {obs }}$ for

$120 \mathrm{O}_{2}^{-}$disproportionation at $\mathrm{pH}$ values above 7. According to this relationship, secondary stock

121 concentrations only decrease by $\sim 0.002 \mu \mathrm{M} \mathrm{O}_{2}{ }^{-}$within the length of a typical calibration procedure $122(500 \mathrm{~s})$.

$$
k_{\text {obs }}\left(\mathrm{M}^{-1} \mathrm{~s}^{-1}\right)=6.0 \times 10^{12}\left[\mathrm{H}^{+}\right] \text {for } \mathrm{pH}>7
$$

123 Standard solutions are prepared by placing $\mu \mathrm{L}$ aliquots of the secondary $\mathrm{O}_{2}^{-}$stock into stirred

124 borate buffer solutions at $\mathrm{pH}$ 9. Dilution schemes are designed to span four orders of signal 125 magnitude. Note that each calibration standard (Figure S8) decreases in signal after peak 126 chemiluminescence. Theoretical chemiluminescence (and thus $\mathrm{O}_{2}^{-}$concentration) at the time of 127 aliquot addition $\left(t_{0}\right)$ was calculated by a second-order decay curve.

\section{S5. Interference Studies for Chemiluminescent Reagent}

It is crucial to use a selective chemiluminescence probe for quantitative analysis of $\mathrm{O}_{2}^{-}$.

130 Several aqueous nitrate photoproducts $\left(\mathrm{NO}_{2}, \mathrm{NO}, \mathrm{NO}_{2}^{-}\right.$, and $\left.\mathrm{H}_{2} \mathrm{O}_{2}\right)$ were determined to be 
131 nonreactive with methyl cypridina luciferin analog (MCLA). All solutions were buffered at pH 6 132 with phosphate. $\mathbf{N O}_{(\mathrm{aq})}$ and $\mathbf{N O}_{2(\mathrm{aq})}$. In darkness, $20 \mathrm{ppm} \mathrm{NO}_{2(\mathrm{~g})}$ and $10 \mathrm{ppm} \mathrm{NO}_{(\mathrm{g})}\left(\right.$ in $\mathrm{N}_{2}$ ) were individually 134 bubbled into a solution chilled to $0{ }^{\circ} \mathrm{C}$ for 2 hours. Both solutions yielded less signal than the 135 control experiment, because $\mathrm{NO}_{(\mathrm{aq})}$ and $\mathrm{NO}_{2(\mathrm{aq})}$ efficiently scavenges background superoxide in 136 solution. $^{6}$

Nitrite $\left(\mathrm{NO}_{2}{ }^{-}\right)$. Solutions of $100 \mu \mathrm{M} \mathrm{NO}_{2}^{-}$were prepared with $\mathrm{NaNO}_{2}$ (Sigma Aldrich, $\geq 99 \%$ ). No noticeable signal increase was observed when added to MCLA solutions.

140 (pH 6, phosphate buffered) was reacted with MCLA. However, upon addition of superoxide 141 dismutase (SOD), the signal dropped below ambient levels. This suggests that MCLA 142 chemiluminescence with $\mathrm{H}_{2} \mathrm{O}_{2}$ may be from the cycling of reactive oxygen species and production 143 of $\mathrm{O}_{2}^{-}$, likely initiated by ambient light photolysis of $\mathrm{H}_{2} \mathrm{O}_{2}$ to form $\mathrm{H}_{2} \mathrm{O}$ and $\mathrm{HO}_{2}$.

Ozone $\left(\mathbf{O}_{3}\right)$. No reaction between $\mathrm{O}_{3}$ and MCLA was detected. Imidazole rapidly reacts with ozone $\left(2.3 \times 10^{5} \mathrm{M}^{-1} \mathrm{~s}^{-1}\right),{ }^{7}$ and was used as a scavenger during irradiation of nitrate solutions with NNA. No signal decrease was observed when solutions of imidazole (1 mM, $10 \mathrm{mM})$ were 147 mixed at a ratio of 1:1 with the sample line before entering the FeLume. This indicates no observed 148 signal is due to ozone reactions with MCLA. Both imidazole solutions contained $50 \mu \mathrm{M}$ DTPA 149 and $5 \mathrm{mM}$ phosphate buffer. Additionally, DTPA showed no reactivity toward ozone. Two controls 150 without imidazole were tested, both contained phosphate buffer but only one contained $50 \mu \mathrm{M}$

151 DTPA. The lack of a difference in signal between these controls indicate ozone does not react 152 quickly with DTPA. 
Other Potential Interferences. Rose et al. ${ }^{1}$ determined that some trace metals may elicit

154 MCLA chemiluminescence due to the reduction-oxidation cycling between $\mathrm{O}_{2}^{-}$and $\mathrm{O}_{2}$ with $\mathrm{M}^{+n}$ 155 and $\mathrm{M}^{+n-1}$. Metals responsible for most MCLA background interference are $\mathrm{Fe}, \mathrm{Mo}, \mathrm{V}$, and $\mathrm{Cu}$,

156 with 10-100 nM samples causing chemiluminescence equivalent to 20-280 $\mathrm{nM} \mathrm{O}_{2}^{-}$. To prevent 157 trace metal contamination, all glassware was acid-washed and covered with aluminum foil when 158 not in use. All solutions were prepared in a devoted fume hood that was kept clean to minimize 159 metal contamination.

\section{S6. HONO Production at High pH}

Acid-base speciation of $\mathrm{HONO}_{(\mathrm{aq})}(\mathrm{pKa}=3.4)$ greatly affects rates of $\mathrm{HONO}_{(\mathrm{g})}$ emission.

Figure $\mathrm{S} 3 \mathrm{~B}$ shows that lower $\mathrm{HONO}_{(\mathrm{g})}$ emissions are observed when phosphate-buffered $\mathrm{NO}_{3}{ }^{-}$

163 solutions were photolyzed at $\mathrm{pH}=7.8$ ( similar to the $\mathrm{pH}$ of the ocean) compared to those produced

164 at $\mathrm{pH}=6$ (see Figures $1 \mathrm{~B}$ and $1 \mathrm{D})$; similar levels are produced with or without nonanoic acid since

$165 \mathrm{NO}_{2}^{-}$(aq) is the dominant species at $\mathrm{pH} 7.8$, which is nearly $5 \mathrm{pH}$ units above the $\mathrm{p} K_{\mathrm{a}}$ of $\mathrm{HONO}_{(\mathrm{aq}) \cdot}{ }^{8}$

166 When the $\mathrm{pH}$ was adjusted to 5, much greater $\mathrm{HONO}_{(\mathrm{g})}$ concentrations were observed (Figure 2).

167 Therefore, $\mathrm{pH}$ is a critical variable that affects $\mathrm{HONO}_{(\mathrm{g})}$ emission rates. This was demonstrated in

168 Scharko et al. who observed that four times more $\mathrm{HONO}_{(\mathrm{g})}$ than $\mathrm{NO}_{2(\mathrm{~g})}$ was emitted at $\mathrm{pH}$ values

169 less than $2 .{ }^{8}$ Nitrate photolysis in alkaline environments, such as the ocean $(\mathrm{pH}=8)$, would have

170 much lower $\mathrm{HONO}_{(\mathrm{g})}$ emissions than would be observed for more acidic aqueous environments

171 such aerosols.

\section{S7. Possible Factors Impacting Gaseous $\mathrm{NO}_{2}$ and HONO Concentrations in Figure 1}

Complex secondary photochemistry occurs following nitrate photolysis, and multiple

174 factors affect experimental observations of $\mathrm{NO}_{(\mathrm{g})}, \mathrm{NO}_{2(\mathrm{~g})}, \mathrm{HONO}_{(\mathrm{g})}$, and $\mathrm{O}_{2}^{-}$(aq) . Static experiments 
175 will produce data different than stirred experiments due to differences in solution homogeneity.

176 The diffusion limitation of the static system can influence the release of $\mathrm{NO}_{2(\mathrm{aq})}$ and $\mathrm{HONO}_{(\mathrm{aq})}$ into

177 the gas phase due to diffusion gradients that form in solution as mass-transport to the gas phase

178 only occurs at the surface. This issue does not apply to stirred systems. The addition of organics

179 may also change $\mathrm{NO}_{2}$ and $\mathrm{HONO}$ solubility in the nitrate solution. ${ }^{9}$ Some static experiments in this

180 study contained surface-active organics (Figures 1A-B), which would generate a surface

181 microlayer of organics that may affect mass-transport of $\mathrm{NO}_{\mathrm{y}}$ in juxtaposition to solutions with

182 homogenous DAOM. ${ }^{9}$

The amount of $\mathrm{NO}_{2(\mathrm{~g})}$ produced is controlled by the total pool of aqueous $\mathrm{OH}+\mathrm{HO}_{2} / \mathrm{O}_{2}^{-}+$

$184 \mathrm{RO}_{2}$, which is in turn determined by the true nitrate photolysis rate. While the nitrate photolysis

185 rate is theoretically constant regardless of the presence of DAOM, different products $\left(\mathrm{NO}_{3}^{-}{ }^{-}\right.$or $\left.\mathrm{NO}_{2}^{-}\right)$

186 result when $\mathrm{OH}_{(\mathrm{aq})}$ or $\mathrm{O}_{2}^{-}$(aq) react with $\mathrm{NO}_{2 \text { (aq). }}$. Thus, it is the ratio of $\mathrm{O}_{2}^{-}$(aq) $\mathrm{vs} \mathrm{OH}_{(\mathrm{aq})}$

187 concentrations that affect the relative $\mathrm{HONO}_{(\mathrm{g})}$ yield, whereas $\mathrm{RO}_{2(\mathrm{aq})}$ is an $\mathrm{NO}_{2(\mathrm{aq})}$ sink and does

188 not form or react with $\mathrm{HONO}_{(\mathrm{aq})} \cdot{ }^{10}$ Taken together, the observed yield of $\mathrm{NO}_{2}{ }^{-}$is higher when

189 nitrate is photolyzed in the presence of organic matter due to the $\mathrm{OH}$ scavenger effect (which

190 prevents reformation of nitrate) and the secondary photochemical $\mathrm{NO}_{2}$-to-HONO conversion

191 driven by a higher $\left[\mathrm{HO}_{2}+\mathrm{O}_{2}^{-}\right]:[\mathrm{OH}]$ ratio.

192 Surface-active organics (Figure 1A-B) show relatively similar concentrations of $\mathrm{NO}_{2(\mathrm{~g})}$,

193 although background-subtracted integration of $\mathrm{NO}_{2(\mathrm{~g})}$ emissions shows a net $\mathrm{NO}_{2(\mathrm{~g})}$ increase for

194 NNA solutions and a net $\mathrm{NO}_{2(\mathrm{~g})}$ decrease for octanol solutions (Table S1). Both DAOM species

195 have similarly fast reaction rates with $\mathrm{OH}_{(\mathrm{aq})}$, therefore effectively scavenging most $\mathrm{OH}_{(\mathrm{aq})}$ which

196 would otherwise recombine with $\mathrm{NO}_{2(\text { aq) }}$ to reform $\mathrm{NO}_{3}{ }^{-}$(aq). . The difference is most likely caused

197 by total $\mathrm{O}_{2}^{-}$production rates. Note that, while superoxide measurements were made under stirred 
198 conditions, octanol produced twice as much $\mathrm{O}_{2}{ }^{-}$than NNA caused by differences in $\mathrm{RO}_{2}$ chemistry,

199 described later in this section. Higher $\mathrm{O}_{2}{ }^{-}$scavenging would lead to more $\mathrm{NO}_{2}$ consumption. The

200 higher $\mathrm{NO}_{2(\mathrm{~g})}$ emissions from NNA solutions is likely due to a net decrease in the localized $\mathrm{HO}_{\mathrm{x}}$

201 budget due to fast $\mathrm{OH}$ scavenging and comparably slower $\mathrm{RO}_{2}$ decomposition to $\mathrm{HO}_{2}$ than is 202 observed for aliphatic alcohols.

203 Small differences are observed for production of HONO from surface-active organic 204 experiments. These experiments showed a unique initial production burst of HONO from $t=18 \mathrm{~min}$ $205-25 \mathrm{~min}$, which could be from a relatively fast $\mathrm{NO}_{2}$-to-HONO conversion rate before diffusion 206 gradients are generated as surface reactants become depleted. This may indicate that, if completely 207 mixed, a single linear trend should be observed much like the data observed for homogenous 208 DAOM (Figure 1D). Overall, the HONO-to- $\mathrm{NO}_{2}$ conversion enhancement factor $\left(R_{\text {enahance }}\right)$ were 209 very similar, with an average factor increase of $2.77 \pm 0.17$ compared to pure nitrate solutions The observed increase in $\mathrm{NO}_{2(\mathrm{~g})}$ concentration in Figure $1 \mathrm{C}$ is due to differences in DAOM 211 mixing, $\mathrm{HO}_{\mathrm{x}(\mathrm{aq})}$ accumulation rates, and depletion of DAOM over time. Experiments in Figure 1C-

212 D use homogenous organic substrates, meaning that reactants are more evenly distributed 213 throughout the bulk solution. The $\mathrm{NO}_{2(\mathrm{~g})}$ concentration starts out low compared to what is observed 214 in Figure 1A since early in the experiment $\mathrm{HO}_{\mathrm{x}}$ levels are high and react with $\mathrm{NO}_{2}$, keeping its 215 concentration low. As the reaction proceeds, $\mathrm{OH}$ depletes the DOAM concentration and the pool 216 of $\mathrm{HO}_{\mathrm{x}}$ begins to decrease, causing $\mathrm{NO}_{2(\mathrm{aq})}$ levels to increase over time as less $\mathrm{NO}_{2}$ is consumed.

217 The homogenous DAOM used in this study have fewer C-H bond equivalents than the surface218 active organics and would be more completely oxidized by $\mathrm{OH}_{(\mathrm{aq})}$. It is notable that by the end of 219 the experiment shown in Figure $1 \mathrm{C}$, the $\mathrm{NO}_{2(\mathrm{~g})}$ concentration has reached the concentrations 220 observed for the surface-active organics (octanol and nonanoic acid). 
In the case of surface-active organics (Figure 1A, B), the DOAM is concentrated at the

222 surface, whereas $\mathrm{NO}_{3}^{-}$(aq) is located throughout the bulk solution. As a result, far less $\mathrm{OH}_{(\mathrm{aq})}$ would 223 be converted to $\mathrm{RO}_{2(\mathrm{aq})}$ and $\mathrm{O}_{2}^{-}$(aq) by organic scavenging within the bulk. Since $\mathrm{O}_{2}^{-}$(aq) is a more 224 stable oxygen radical, it accumulates to larger (nM) concentrations than is possible for $\mathrm{OH}$ (fM).

225 Since both $\mathrm{HO}_{\mathrm{x}(\mathrm{aq})}$ species have the same reaction rate with $\mathrm{NO}_{2(\mathrm{aq})}\left(k=4.5 \times 10^{9} \mathrm{M}^{-1} \mathrm{~s}^{-1}\right)$, better $226 \mathrm{NO}_{2(\mathrm{aq})}$ scavenging is observed when soluble organic matter is present to convert $\mathrm{OH}_{(\mathrm{aq})}$ to $\mathrm{O}_{2}^{-}$(aq) 227 and generate a much larger concentrations of $\mathrm{HO}_{\mathrm{x}(\mathrm{aq})}$. It should be noted that without solution 228 mixing, the observed gaseous analytes are most reflective of chemistry occurring at or near the air229 water interface, which become more depleted in analyte concentrations compared to the bulk due 230 to volatilization. This forms concentration gradients in solution that may not reflect average bulk 231 concentration.

232 Production of HONO had a higher variably for homogenous DAOM solutions (Figure 1D) 233 than the tested surface-active substrates. On average, the HONO-to- $\mathrm{NO}_{2}$ conversion enhancement 234 factor $\left(R_{\text {enahance }}\right)$ for homogeneous DAOM was $3.73 \pm 1.17$, which is about $25 \%$ higher than that of 235 surface active organics. However, the high standard deviations make these values statistically 236 insignificant. The differences in HONO production between homogeneous DAOM are likely due 237 to considerations of $\mathrm{RO}_{2}$ stability and $\mathrm{O}_{2}^{-}$accumulation rates.

238 The concentration of DAOM and its molecular structure affects the rates of $\mathrm{OH}_{(\mathrm{aq})}$ 239 scavenging, $\mathrm{RO}_{2(\mathrm{aq})}$ production, and subsequent $\mathrm{RO}_{2(\mathrm{aq})}$ decay to form the observed $\mathrm{O}_{2}^{-}$(aq). 240 Solutions without DAOM would have higher steady-state concentrations of $\mathrm{OH}_{(\mathrm{aq})}$ radical, which 241 oxidizes $\mathrm{NO}_{2(\mathrm{aq})}$ and $\mathrm{HONO}_{(\mathrm{aq})}$ back to $\mathrm{HNO}_{3(\mathrm{aq})}$ in reactions with rate constants near the kinetic 242 diffusion limit. ${ }^{8}$ Fatty acids are poorer $\mathrm{OH}_{(\mathrm{aq})}$ scavengers than aliphatic alcohols, ${ }^{11}$ which would 243 lead to comparatively higher ambient $\mathrm{OH}_{(\mathrm{aq})}$ concentrations and therefore more $\mathrm{NO}_{\mathrm{y}(\mathrm{aq})}$ oxidation 
244 for the former organic scavenger. ${ }^{8}$ Differences in $\mathrm{RO}_{2(\mathrm{aq})}$ production rates are affected by $\mathrm{OH}_{(\mathrm{aq})}$ 245 reaction rates, which also affect ambient levels of $\mathrm{OH}_{(\mathrm{aq})}$ between different DAOM solutions (Table 246 S2). Aliphatic alcohols react with $\mathrm{OH}_{(\mathrm{aq})}$ much faster than fatty acids to produce $\alpha$ -

247 hydroperoxylradicals that spontaneously react intramolecularly to directly form $\mathrm{O}_{2}^{-}{ }_{(\mathrm{aq})}{ }^{12}$ Fatty 248 acids produce $\mathrm{RO}_{2(\text { aq) }}$ species with comparatively lower energy than $\alpha$-hydroperoxylradicals, and 249 produce $\mathrm{O}_{2}^{-}{ }_{(\mathrm{aq})}$ at a slower rate though a multi-step disproportionation pathway, instead of direct 250 intramolecular decay. ${ }^{11}$ All reactive oxygen species (ROS) produced have different reaction rates 251 with other intermediates in solution, such as $\mathrm{NO}_{2(\mathrm{aq})}$ and $\mathrm{HONO}_{(\mathrm{aq})} \cdot{ }^{8,10,13}$ When DAOM is added, $252 \operatorname{most~} \mathrm{OH}_{(\mathrm{aq})}$ radical is scavenged and leads to the secondary production of $\mathrm{RO}_{2(\mathrm{aq})}$ and superoxide. 253 Superoxide, a strong reducing agent, also scavenges $\mathrm{NO}_{\mathrm{x}(\mathrm{aq})}$. It reacts with $\mathrm{NO}_{2(\mathrm{aq})}$ and $\mathrm{NO}_{(\mathrm{aq})}$ at 254 rates near the diffusion limit $\left(4.5 \times 10^{9} \mathrm{M}^{-1} \mathrm{~s}^{-1}\right.$ and $4.3 \times 10^{9} \mathrm{M}^{-1} \mathrm{~s}^{-1}$, respectively), ${ }^{14,15}$ leading to the 255 production of $\mathrm{OONO}_{2}^{-}{ }_{(\mathrm{aq})}^{-}$and $\mathrm{OONO}_{(\text {(aq) }}^{-}$, and subsequently $\mathrm{NO}_{2}^{-}{ }_{(\mathrm{aq})}{ }^{16}$ If the ROS pool favors accumulation of $\mathrm{RO}_{2(\text { aq) }}$, much slower $\mathrm{NO}_{\mathrm{x}}$-to- $\mathrm{NO}_{2}{ }^{-}$conversion rates 257 would be observed due to the slower $\mathrm{O}_{2}^{-}$(aq) production rate. Alkylperoxy-nitrates and -nitrites 258 would also accumulate to higher concentrations, as $\mathrm{RO}_{2(\text { aq) }}$ is also a significant scavenger for $\mathrm{NO}_{2 \text { (aq) }}$ 259 and $\mathrm{NO}_{(\mathrm{aq})}$ with fast reaction rates $\left(1.1 \times 10^{9} \mathrm{M}^{-1} \mathrm{~s}^{-1}\right.$ and $1-3 \times 10^{9} \mathrm{M}^{-1} \mathrm{~s}^{-1}$, respectively). ${ }^{10,17}$ $260 \mathrm{ROONO}_{(\mathrm{aq})}$ and $\mathrm{ROONO}_{2(\mathrm{aq})}$ species have relatively high stability with chemical lifetimes between

$2611 \mathrm{~s}$ and $100 \mathrm{~s}$. Data from Goldstein et al. (2004) suggest that $\mathrm{RO}_{2} \mathrm{NO}_{2 \text { (aq) }}$ does not yield $\mathrm{NO}_{2}{ }^{-}$(aq) 262 directly, but rather dissociates back into $\mathrm{RO}_{2(\text { aq) }}$ and $\mathrm{NO}_{2(\mathrm{aq})}$ at slow rates. ${ }^{10}$ They also state that 263 these species have no absorption above $270 \mathrm{~nm}$, so their photochemistry is negligible in our system. 
The objective of this experiment was to investigate the relationship between $\mathrm{HO}_{2} / \mathrm{O}_{2}^{-}$(aq), $267 \mathrm{NO}_{\mathrm{x}(\mathrm{g})}$, and $\mathrm{HONO}_{(\mathrm{g})}$ formed during photolysis of nitrate solutions containing DAOM surrogates.

268 To do this, we titrated photolyzed solutions of nitrate with $\mathrm{HO}_{2} / \mathrm{O}_{2}{ }^{-}$(aq) formed from the reaction of $269 \mathrm{OH}_{(\mathrm{aq})}$ with added ethanol. This approach offers the simplest way to boost $\mathrm{HO}_{2} / \mathrm{O}_{2}{ }^{-}$(aq) 270 concentrations while avoiding potential ambiguities in data interpretation introduced with other 271 superoxide sources (e.g., potassium superoxide $\left(\mathrm{KO}_{2}\right)+$ crown ethers or xanthine/xanthine 272 oxidase).

Using the same experimental setup as described in section $\mathrm{S} 3$, a $50 \mathrm{~mL}$ aliquot of a $\mathrm{pH} 5$ solution composed of $10 \mathrm{mM} \mathrm{NO}_{3}^{-}, 1 \mathrm{mM} \mathrm{NNA}, 100 \mathrm{mM} \mathrm{PO}_{4}{ }^{3-}$ was continuously flowed through a stirred reaction cell. Solution levels were maintained at $50 \mathrm{~mL}$ by the simultaneous removal and

276 addition of experimental solution at $2.3 \mathrm{~mL} \mathrm{~min}{ }^{-1}$. The reactor headspace $\left(\sim 130 \mathrm{~cm}^{3}\right)$ was 277 continuously purged ( $1.7 \mathrm{~L} \mathrm{~min}^{-1}, 4.6 \mathrm{~s}$ residence time) with purified, dry air. We calculate a HONO 278 and $\mathrm{NO}_{2}$ photolysis rate of $5.0 \times 10^{-3} \mathrm{~s}^{-1}$ and $1.62 \times 10^{-2} \mathrm{~s}^{-1}$ for our source, respectively. With a $2794.6 \mathrm{~s}$ headspace residence time, only $2.3 \%$ of emitted HONO would be photolyzed, whereas up to $2807.5 \%$ of $\mathrm{NO}_{2}$ is photolyzed. This could marginally affect our data for observed $\mathrm{HONO}, \mathrm{NO}_{2}$, and 281 NO, although we compare all ethanol titration experiments to the nitrate + NNA control experiment 282 so the gas phase chemistry should be similar. Most importantly, the $\mathrm{NO}_{(\mathrm{g})}$ observed resulted from 283 the photolysis of $\mathrm{HONO} / \mathrm{NO}_{2}{ }^{-}$and $\mathrm{NO}_{2}$ in the photochemical chamber. Concentrations of $\mathrm{NO}_{(\mathrm{g})}, \mathrm{NO}_{2(\mathrm{~g})}$, and $\mathrm{HONO}_{(\mathrm{g})}$ were measured within $3 \mathrm{~s}$ by a custom-built 285 single-channel $\mathrm{NO}_{\mathrm{x}}$ chemiluminescence detector (Air Quality Design, Inc., Golden, Colorado). ${ }^{18}$ 286 Briefly, measurements proceeded as follows: 1) sampled air was first drawn through a zero volume 
287 where it reacted with $\mathrm{O}_{3(\mathrm{~g})}$ generated internally by a corona discharge allowing for a background 288 measurement due to the short $\mathrm{NO}_{2(\mathrm{~g})}$ chemiluminescence lifetime; 2) The $\mathrm{O}_{3(\mathrm{~g})}$ was diverted to the 289 a reaction cell connected to a photomultiplier tube, which allows detection of luminescent radiation 290 that is directly proportional to the $\mathrm{NO}_{(\mathrm{g})}$ mixing ratio; 3) Sampled air was passed through a modified 291 photolysis cell equipped with two LEDs with peak wavelengths $395 \mathrm{~nm}$ and $385 \mathrm{~nm}$ respectively, 292 the LEDs are cycled sequentially to determine the concentration of $\mathrm{NO}_{2(\mathrm{~g})}$ and $\mathrm{HONO}_{(\mathrm{g})}$ by 293 differential photolysis. This technique is described in more detail by Reed et al. ${ }^{18}$ A multipoint 294 calibration with a standard tank of $\mathrm{NO}_{(\mathrm{g})}(4.61 \pm 0.10 \mathrm{ppm}$, verified by Praxair) performed before

295 the experiment showed a limit of detection of $136 \mathrm{ppt}$ for $\mathrm{NO}_{(\mathrm{g})}$. Using the lower conversion 296 efficiency of the two LEDs for $\mathrm{NO}_{2(\mathrm{~g})}$ and $\mathrm{HONO}(0.50)$ found limits of detection for the two gases 297 of $144 \mathrm{ppt}\left(\mathrm{NO}_{2}\right)$ and $272 \mathrm{ppt}(\mathrm{HONO})$.

The continuously stirred tank reactor was air-tight during $\mathrm{NO}_{(\mathrm{g})}$ calibration and titration 299 experiments. During the experiments displayed in Figure 2, the solution was irradiated for $25 \mathrm{~min}$ 300 before addition of a $100 \mu \mathrm{L}$ aliquot of a solution containing $1.5 \mathrm{M}$ ethanol and $50 \mu \mathrm{M}$ DTPA. The 301 solution used for the control experiment was a $100 \mu \mathrm{L}$ aliquot of a solution containing only $50 \mu \mathrm{M}$ 302 DTPA. A second aliquot of either ethanol or the control solution was added at $t=45 \mathrm{~min}$, a full 20 303 min after the first addition. After another $20 \mathrm{~min}$, the light was extinguished and sampled for an 304 extra $\sim 20 \mathrm{~min}$. 


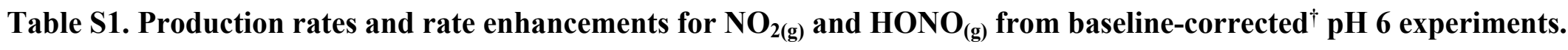

\begin{tabular}{|c|c|c|c|c|c|c|c|c|c|c|}
\hline Solutions & $\begin{array}{l}P\left(\mathrm{NO}_{2}\right)^{\mathrm{a}} \\
\left(\mathrm{ppb} \mathrm{hr}{ }^{-1}\right)\end{array}$ & $\begin{array}{c}P(\mathrm{HONO})^{\mathrm{a}} \\
\left.(\mathrm{ppb} \mathrm{hr})^{-1}\right)\end{array}$ & $\begin{array}{l}P\left(\mathrm{NO}_{2}+\right. \\
\mathrm{HONO})^{\mathrm{a}} \\
(\mathrm{ppb} \mathrm{hr}-1)\end{array}$ & $R_{\mathrm{HONO}: \mathrm{NO} 2}{ }^{\mathrm{b}}$ & $R_{\text {enhance }}{ }^{\mathrm{c}}$ & 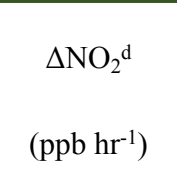 & $\begin{array}{l}\Delta \mathrm{HONO}^{\mathrm{d}} \\
\left(\mathrm{ppb} \mathrm{hr}{ }^{-1}\right)\end{array}$ & $\begin{array}{l}\text { Factor } \\
\text { change, } \\
R\left(\mathrm{NO}_{2}\right)\end{array}$ & $\begin{array}{c}\text { Factor } \\
\text { change, }{ }^{\mathrm{e}} \\
R(\mathrm{HONO})\end{array}$ & $\begin{array}{c}\text { Factor change, } \\
R\left(\mathrm{NO}_{2}+\right. \\
\mathrm{HONO})^{\mathrm{e}}\end{array}$ \\
\hline $\mathrm{NO}_{3}^{-}$only & $275.3 \pm 0.4$ & $10.82 \pm 0.04$ & $286.1 \pm 0.3$ & 0.039 & 1.00 & - & - & 1.00 & 1.00 & 1.000 \\
\hline+ nonanoic acid & $300.3 \pm 0.5$ & $34.03 \pm 0.09$ & $334.3 \pm 0.4$ & 0.11 & 2.88 & $25.0 \pm 0.4$ & $23.21 \pm 0.07$ & 1.09 & 3.15 & $1.169 \pm 0.001$ \\
\hline+ octanol $^{\mathrm{f}}$ & $252.6 \pm 0.6$ & $26.26 \pm 0.08$ & $278.9 \pm 0.4$ & 0.10 & 2.65 & $-22.7 \pm 0.5$ & $15.44 \pm 0.07$ & 0.92 & 2.43 & $0.975 \pm 0.002$ \\
\hline+ acetic acid & $159.3 \pm 0.5$ & $22.7 \pm 0.06$ & $182.0 \pm 0.4$ & 0.14 & 3.63 & $-116.0 \pm 0.5$ & $11.88 \pm 0.05$ & 0.58 & 2.10 & $0.636 \pm 0.002$ \\
\hline+ valeric acid & $279.3 \pm 0.5$ & $21.24 \pm 0.06$ & $300.5 \pm 0.4$ & 0.076 & 1.93 & $4.0 \pm 0.5$ & $10.42 \pm 0.05$ & 1.01 & 1.96 & $1.050 \pm 0.002$ \\
\hline + ethanol & $220.6 \pm 0.5$ & $44.41 \pm 0.10$ & $265.0 \pm 0.3$ & 0.20 & 5.12 & $-54.7 \pm 0.4$ & $33.59 \pm 0.08$ & 0.80 & 4.10 & $0.926 \pm 0.002$ \\
\hline + propionic acid & $234.6 \pm 0.5$ & $39.16 \pm 0.09$ & $273.8 \pm 0.3$ & 0.17 & 4.25 & $-40.7 \pm 0.4$ & $28.34 \pm 0.07$ & 0.85 & 3.62 & $0.957 \pm 0.002$ \\
\hline $\begin{array}{c}\text { Surface-active } \\
\text { DAOM }\end{array}$ & $276.5 \pm 23.9$ & $30.1 \pm 3.9$ & $306.6 \pm 27.7$ & $0.11 \pm 0.01$ & $2.77 \pm 0.12$ & $1.2 \pm 23.9$ & $19.3 \pm 3.9$ & $1.01 \pm 0.09$ & $2.79 \pm 0.36$ & $1.072 \pm 0.097$ \\
\hline $\begin{array}{c}\text { Homogeneous } \\
\text { DAOM }\end{array}$ & $223.5 \pm 42.9$ & $31.9 \pm 10.1$ & $255.3 \pm 44.3$ & $0.15 \pm 0.05$ & $3.73 \pm 1.17$ & $-51.9 \pm 42.9$ & $21.1 \pm 10.1$ & $0.81 \pm 0.15$ & $2.95 \pm 0.93$ & $0.892 \pm 0.155$ \\
\hline All DAOM & $241.1 \pm 45.2$ & $31.3 \pm 8.6$ & $272.4 \pm 46.4$ & $0.13 \pm 0.04$ & $3.41 \pm 1.06$ & $-34.2 \pm 45.9$ & $20.5 \pm 8.6$ & $0.88 \pm 0.16$ & $2.89 \pm 0.79$ & $0.952 \pm 0.16$ \\
\hline
\end{tabular}

$\dagger$ Average baseline (pre-irradiation) concentrations were subtracted from the dataset to quantify production of $\mathrm{NO}_{2}$ and HONO due solely to photolysis.

308 a $P(i)$ is the production rate of indicated species $\left(i=\mathrm{NO}_{2}, \mathrm{HONO}\right.$, or $\left.\mathrm{NO}+\mathrm{NO}_{2}\right)$ in the various solutions. This is derived by integrating the concentration profiles 309 over the one-hour irradiation period.

$310 \quad{ }^{\mathrm{b}} R_{\mathrm{HONO}: \mathrm{NO} 2}=P(\mathrm{HONO}) / P\left(\mathrm{NO}_{2}\right)$, for each solution

311 c The enhancement in $\mathrm{NO}_{2}$-to-HONO conversion for solutions containing organic molecules relative to pure nitrate solutions is quantified by $R_{\text {enhance }}=$

$312 \quad R_{\mathrm{HONO}: \mathrm{NO} 2}\left(\mathrm{NO}_{3}{ }^{-}+\right.$organic $) / R_{\mathrm{HONO}: \mathrm{NO}_{2}}\left(\mathrm{NO}_{3}{ }^{-}\right.$only)

313 d Difference in photochemical production rates of $\mathrm{HONO}$ or $\mathrm{NO}_{2}$ for solutions containing organic molecules and pure nitrate solutions; e.g., $\Delta \mathrm{NO}_{2}=\left[P\left(\mathrm{NO}_{2}\right)\right.$ for

$314 \quad \mathrm{NO}_{3}^{-}$+organic $]-\left[P\left(\mathrm{NO}_{2}\right)\right.$ for $\mathrm{NO}_{3}^{-}$only $]$

$315 \mathrm{e}^{\mathrm{e}}$ Factor change is the ratio of the production rates for indicated species in nitrate + organic solutions relative to the pure nitrate solution; i.e., $R(\mathrm{i})=P(i)$

$316\left(\mathrm{NO}_{3}{ }^{-}\right.$+organic) $/ P(i)\left(\mathrm{NO}_{3}{ }^{-}\right.$only), where $i=\mathrm{NO}_{2}, \mathrm{HONO}$, or $\mathrm{HONO}+\mathrm{NO}_{2}$.

$317{ }^{\mathrm{f}}$ Includes estimated data points for 63-75 min based on linear experiment trend from $t=27-63 \mathrm{~min}$. 
319 Table S2. OH $(\mathrm{aq})$ reaction rate constants with DAOM surrogates.

\begin{tabular}{lcc}
\hline \multicolumn{1}{c}{ Species } & $\begin{array}{c}k_{O H} \\
\left(10^{8} \mathrm{M}^{-1} \mathrm{~s}^{-1}\right)\end{array}$ & Reference \\
\hline Acetic acid & 0.14 & Thomas 1965 \\
Acetate & 1.0 & Fischer and Hammill 197320 \\
\hline Propionic acid & 6.2 & Scholes and Willson 196721 \\
Propionate & 12 & Logan 198922 \\
\hline Valeric acid & - & - \\
Valerate & 29 & Anbar et al. 1966 \\
\hline Nonanoic acid & - & - \\
\hline Ethanol & 19 & Buxton and Greenstock $1988^{24}$ \\
\hline 1-octanol & 77 & Scholes and Willson $1967^{21}$ \\
\hline
\end{tabular}


321 Table S3. Potential gaseous chemical reactions, $T=298 \mathrm{~K},[\mathrm{M}]=2.7 \times 10^{19}$ molecules $\mathrm{cm}^{-3}$.

\begin{tabular}{ccccc}
\hline \multicolumn{1}{c}{ Reactants } & & Products & Rate coefficient & Reference \\
\hline $\mathrm{HONO}+h v$ & $\rightarrow$ & $\mathrm{NO}+\mathrm{OH}$ & $5.0 \times 10^{-3} \mathrm{~s}^{-1}$ & this work \\
\hline $\mathrm{NO}_{2}+h v$ & $\rightarrow$ & $\mathrm{NO}+\mathrm{O}\left({ }^{3} \mathrm{P}\right)$ & $1.6 \times 10^{-2} \mathrm{~s}^{-1}$ & this work \\
\hline $\mathrm{NO}+\mathrm{NO}_{2}$ & $\rightarrow$ & $\mathrm{N}_{2} \mathrm{O}_{3}$ & $4.8 \times 10^{9} \mathrm{M}^{-1} \mathrm{~s}^{-1}$ & Atkinson et al. 200425 \\
\hline $\mathrm{NO}+\mathrm{OH}+\mathrm{M}$ & $\rightarrow$ & $\mathrm{HONO}$ & $4.6 \times 10^{9} \mathrm{M}^{-1} \mathrm{~s}^{-1}$ & Burkholder et al. 201526 \\
\hline $\mathrm{NO}_{2}+\mathrm{OH}+\mathrm{M}$ & $\rightarrow$ & $\mathrm{HONO}$ & $6.6 \times 10^{9} \mathrm{M}^{-1} \mathrm{~s}^{-1}$ & Burkholder et al. 2015 \\
\hline $\mathrm{NO}+\mathrm{HO}$ & $\rightarrow$ & $\mathrm{HOONO}_{2}$ & $1.1 \times 10^{9} \mathrm{M}^{-1} \mathrm{~s}^{-1}$ & Burkholder et al. 201526 \\
\hline $\mathrm{NO}_{2}+\mathrm{HO}_{2}+\mathrm{M}$ & $\rightarrow$ & $\mathrm{NO}_{2}+\mathrm{OH}$ & $4.8 \times 10^{9} \mathrm{M}^{-1} \mathrm{~s}^{-1}$ & Burkholder et al. 201526 \\
\hline $\mathrm{HONO}^{26} \mathrm{OH}$ & $\rightarrow$ & $\mathrm{HO}_{2} \mathrm{NO}+\mathrm{NO}_{2} \dagger$ & $8.4 \times 10^{8} \mathrm{M}^{-1} \mathrm{~s}^{-1}$ & Burkholder et al. 201526 \\
\hline
\end{tabular}

$323 \dagger$ In their comprehensive study of the $\mathrm{HO}_{2}+\mathrm{NO}_{2}$ reaction, Tyndall et al. ${ }^{27}$ found no evidence that 324 formation of $\mathrm{HONO}$ from peroxynitric acid dissociation in the gas phase; therefore, we expect 325 this reaction has negligible impact on our results. 
327 Table S4. Photolysis rates $j\left(\mathrm{NO}_{3}^{-}\right)$and enhancement factors (EF) for each experiment.

\begin{tabular}{lccccc}
\hline & $\begin{array}{c}\text { Calculated } \\
\left(\mathrm{NO}_{3}^{-}\right)^{\mathrm{a}} \\
\left(\mathrm{s}^{-1}\right)\end{array}$ & $\begin{array}{c}\text { Observed } \\
\left(\mathrm{NO}_{3}^{-}\right)^{\mathrm{b}} \\
\left(\mathrm{s}^{-1}\right)\end{array}$ & $\begin{array}{c}\text { Measured } \\
P\left(\mathrm{NO}_{2}+\mathrm{HONO}\right) \\
(\mathrm{ppb})\end{array}$ & $\begin{array}{c}\text { Predicted } \\
P\left(\mathrm{NO}_{2}\right) \\
(\mathrm{ppb})\end{array}$ & $\mathrm{EF}^{\mathrm{c}}$ \\
\hline $\mathrm{HNO}_{3(\mathrm{~g})}$ & $8.06 \times 10^{-6}$ & & & 431.5 & 1.00 \\
$\mathrm{NO}_{3}^{-}$(aq) & $5.34 \times 10^{-6}$ & & & & 0.66 \\
+ nonanoic acid & & $6.24 \times 10^{-6}$ & 334.3 & & 0.77 \\
+ octanol & $5.21 \times 10^{-6}$ & 278.9 & 0.65 \\
+ acetic acid & $3.40 \times 10^{-6}$ & 182 & 0.42 \\
+ valeric acid & & $5.61 \times 10^{-6}$ & 300.5 & 0.70 \\
+ ethanol & & $4.95 \times 10^{-6}$ & 265 & 0.61 \\
+ propionic acid & & $5.11 \times 10^{-6}$ & 273.8 & & 0.63 \\
\hline Surface-active DAOM & & $5.73 \times 10^{-6}$ & 306.6 & & 0.71 \\
Homogeneous DAOM & & $4.77 \times 10^{-6}$ & 255.3 & & 0.59 \\
All DAOM & $5.09 \times 10^{-6}$ & 272.4 & & 0.64 \\
\hline
\end{tabular}

328 aCalculated using photolysis lamp spectrum

329 bobserved $j\left(\mathrm{NO}_{3}{ }^{-}\right)$determined based on measured product formation rates, $P\left(\mathrm{NO}_{2}+\mathrm{HONO}\right)$, and 330 calculated $j\left(\mathrm{NO}_{3}{ }^{-}\right)$for pure nitrate solutions.

$331{ }^{\mathrm{c}}$ Enhancement factor $(\mathrm{EF})=j\left[\mathrm{NO}_{3}{ }^{-}+\mathrm{DAOM}_{(\mathrm{aq})}\right] / j\left[\mathrm{HNO}_{3(\mathrm{~g})}\right]$ 
A

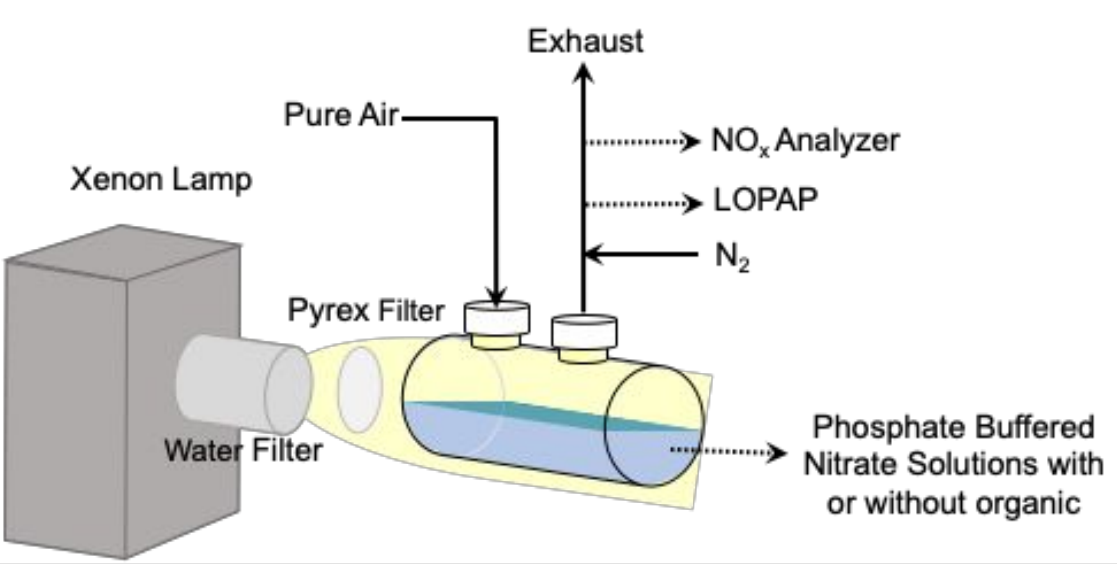

B

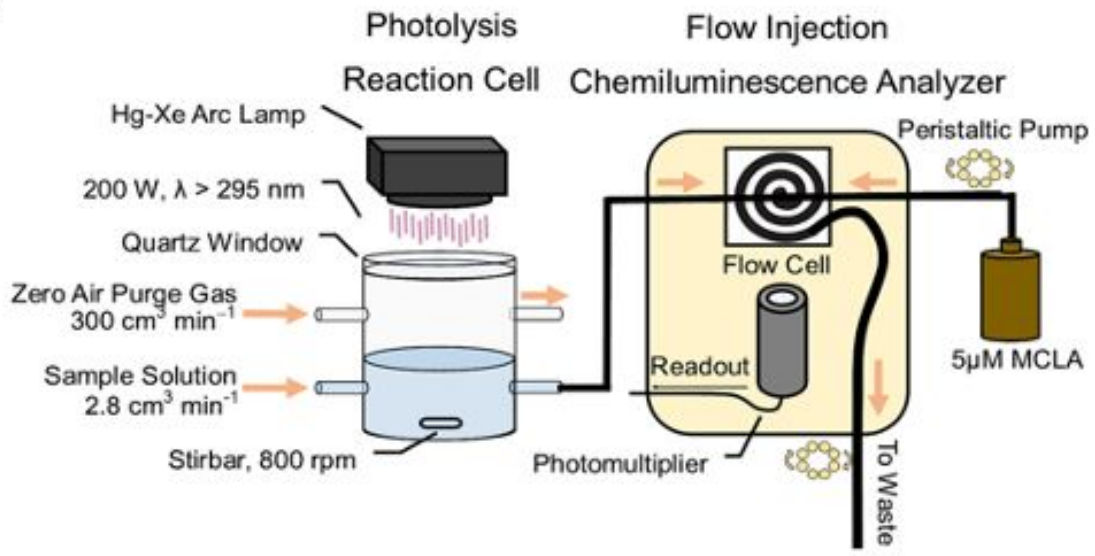

334 Figure S1. Schematics of the experimental setup for (A) $\mathrm{HONO}$ and $\mathrm{NO}_{x}$, and (B) $\mathrm{O}_{2}{ }^{-}$ 335 measurements. 


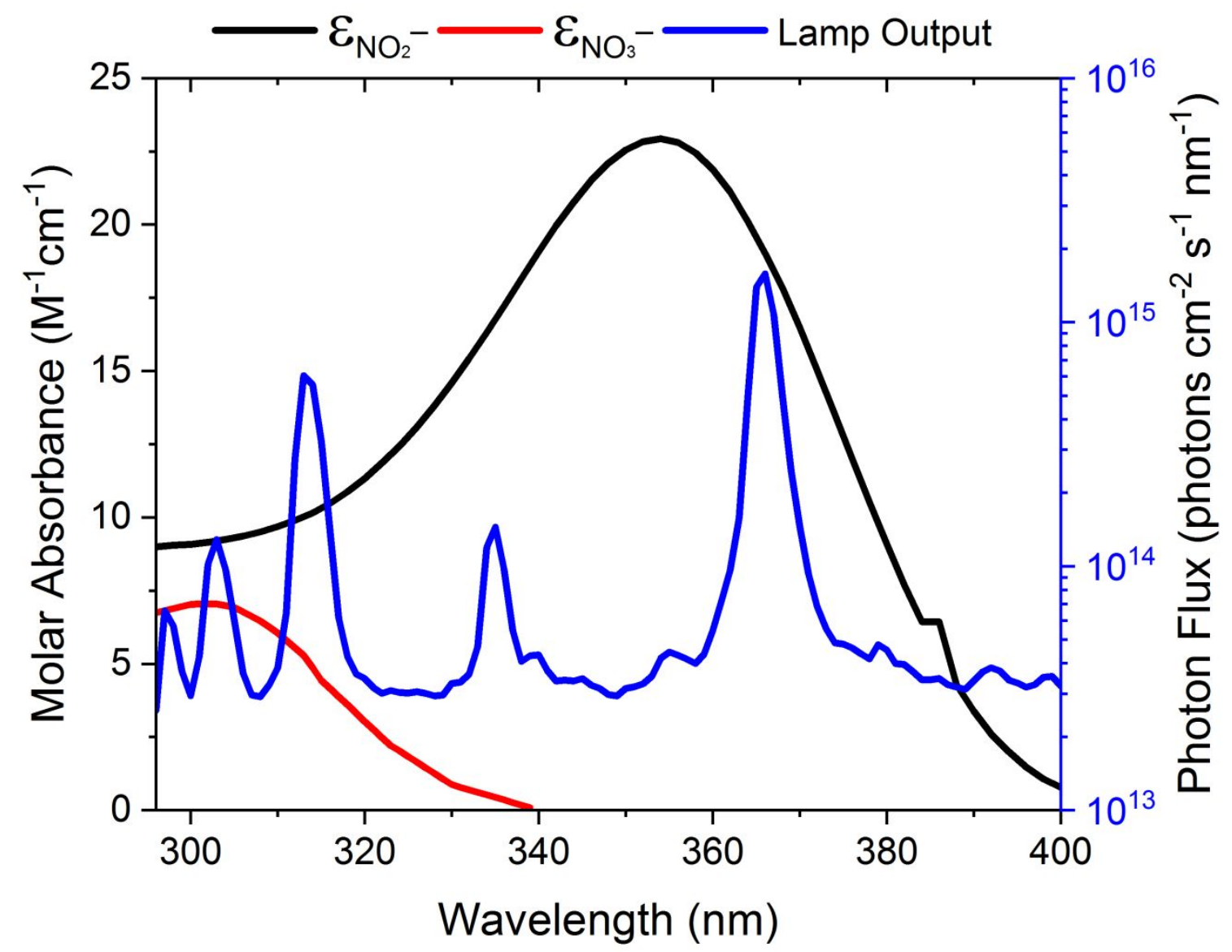

336

337 Figure S2. Experimental lamp irradiance for $\mathrm{O}_{2}^{-}$measurement (blue) overlaid cross sections of

$338 \mathrm{NO}_{3}{ }^{-}$(red) and $\mathrm{NO}_{2}{ }^{-}$(black). Photon flux was determined by chemical actinometry as described in 339 section S3. 

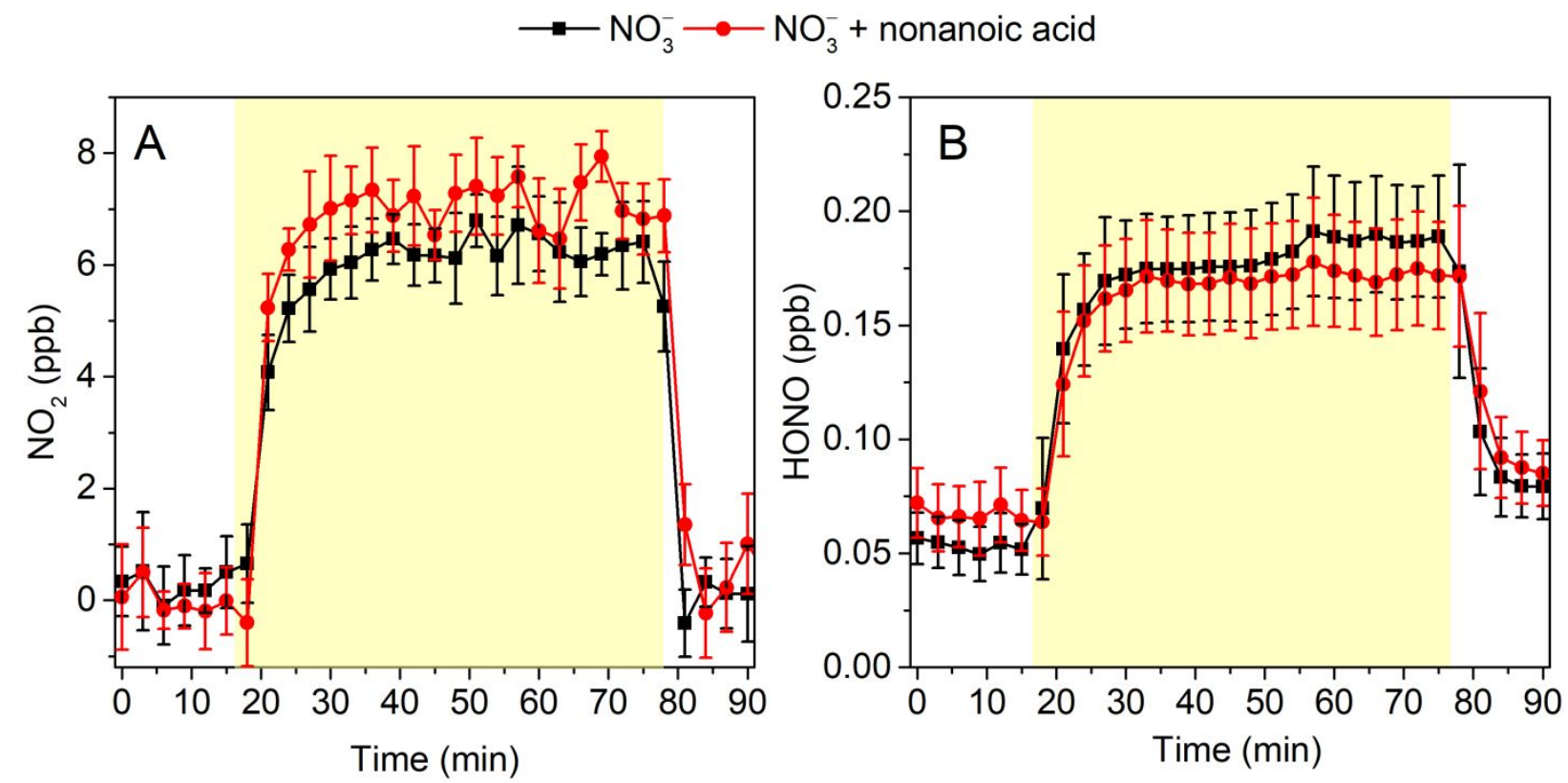

341 Figure S3. The production of $(\mathrm{A}) \mathrm{NO}_{2(\mathrm{~g})}$ and $(\mathrm{B}) \mathrm{HONO}_{(\mathrm{g})}$ during the irradiation of phosphate

342 buffered nitrate solutions ( $\mathrm{pH} 7.8 \pm 0.2)$ in the presence or absence of nonanoic acid, respectively.

343 The yellow region corresponds to the irradiation time (1 hour). 


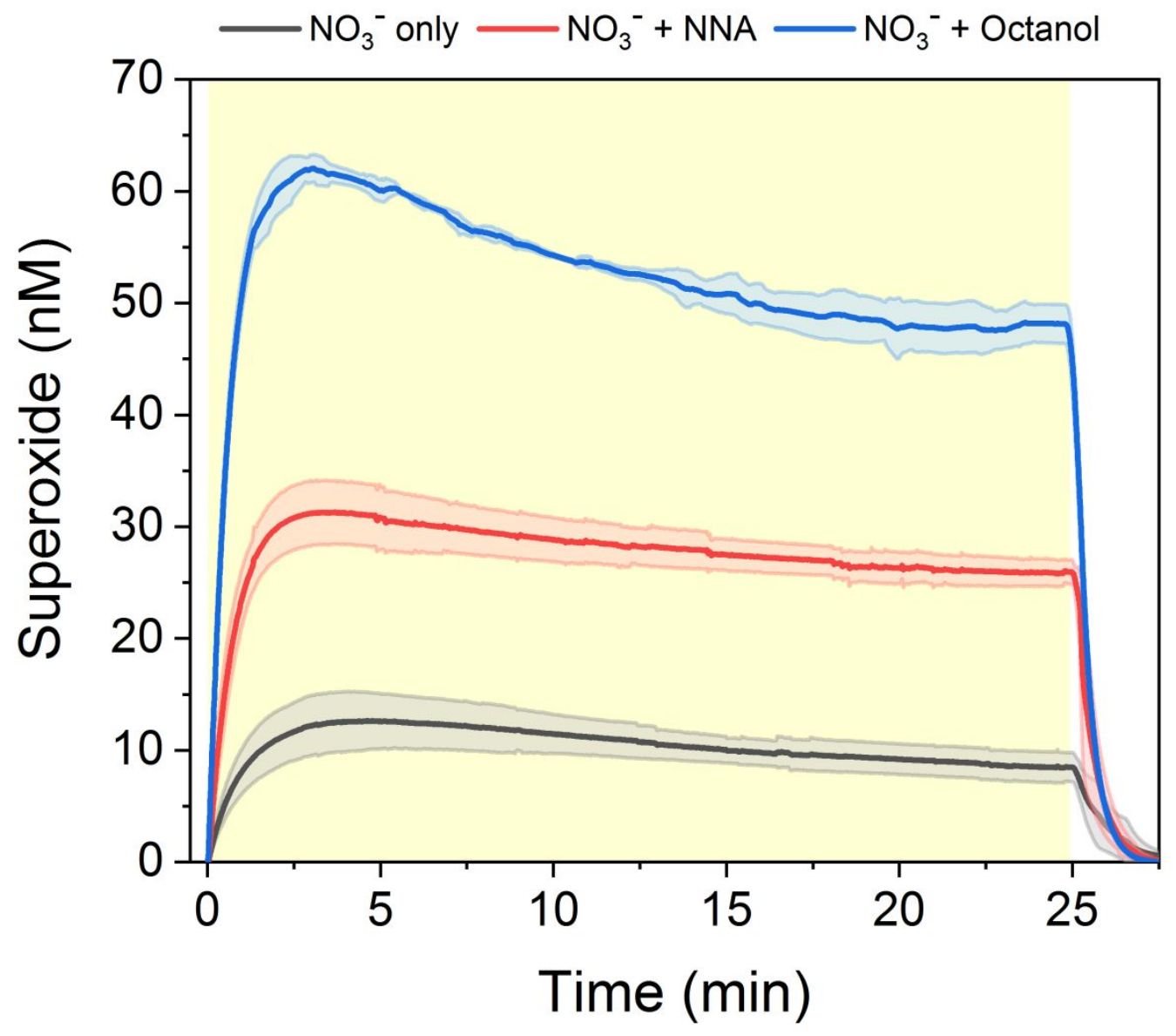

345 Figure S4. Superoxide $\left(\mathrm{O}_{2}^{-}\right)$concentration profiles during irradiation of phosphate buffered ( $\mathrm{pH}$

346 6) solutions consisting of: pure nitrate (black, $n=8$ ); nonanoic acid (red, $n=9$ ) and 1-octanol (blue,

$347 n=3$ ). Solid lines represent the time point average concentration, shaded areas are the time point 348 standard deviation. 


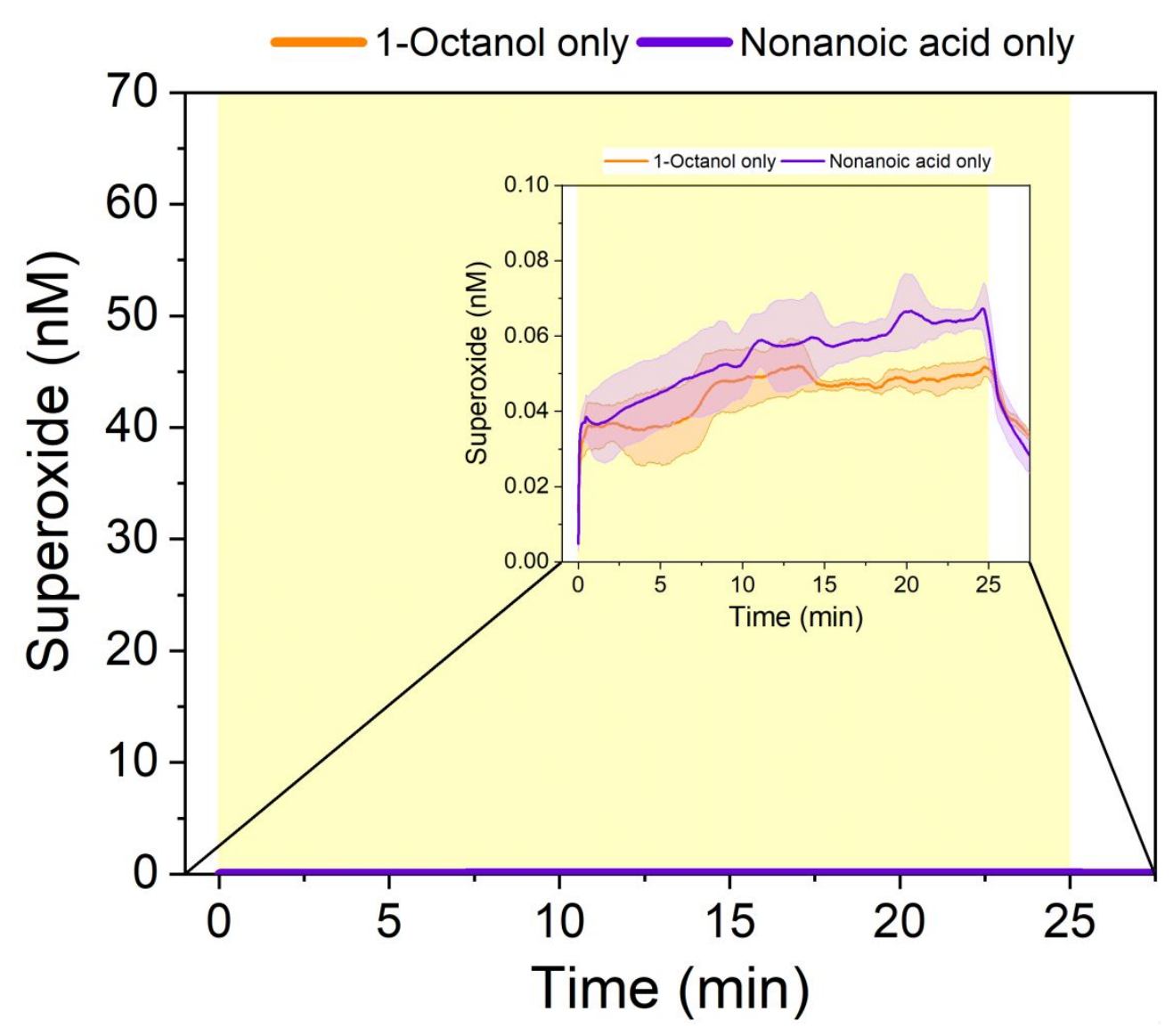

352 Figure S5. Control experiments showing negligible $\mathrm{O}_{2}{ }^{-} / \mathrm{HO}_{2(\mathrm{aq})}$ formed by irradiation of buffered

353 nonanoic acid and 1-octanol solutions without nitrate. The yellow region corresponds to the 354 irradiation time. 


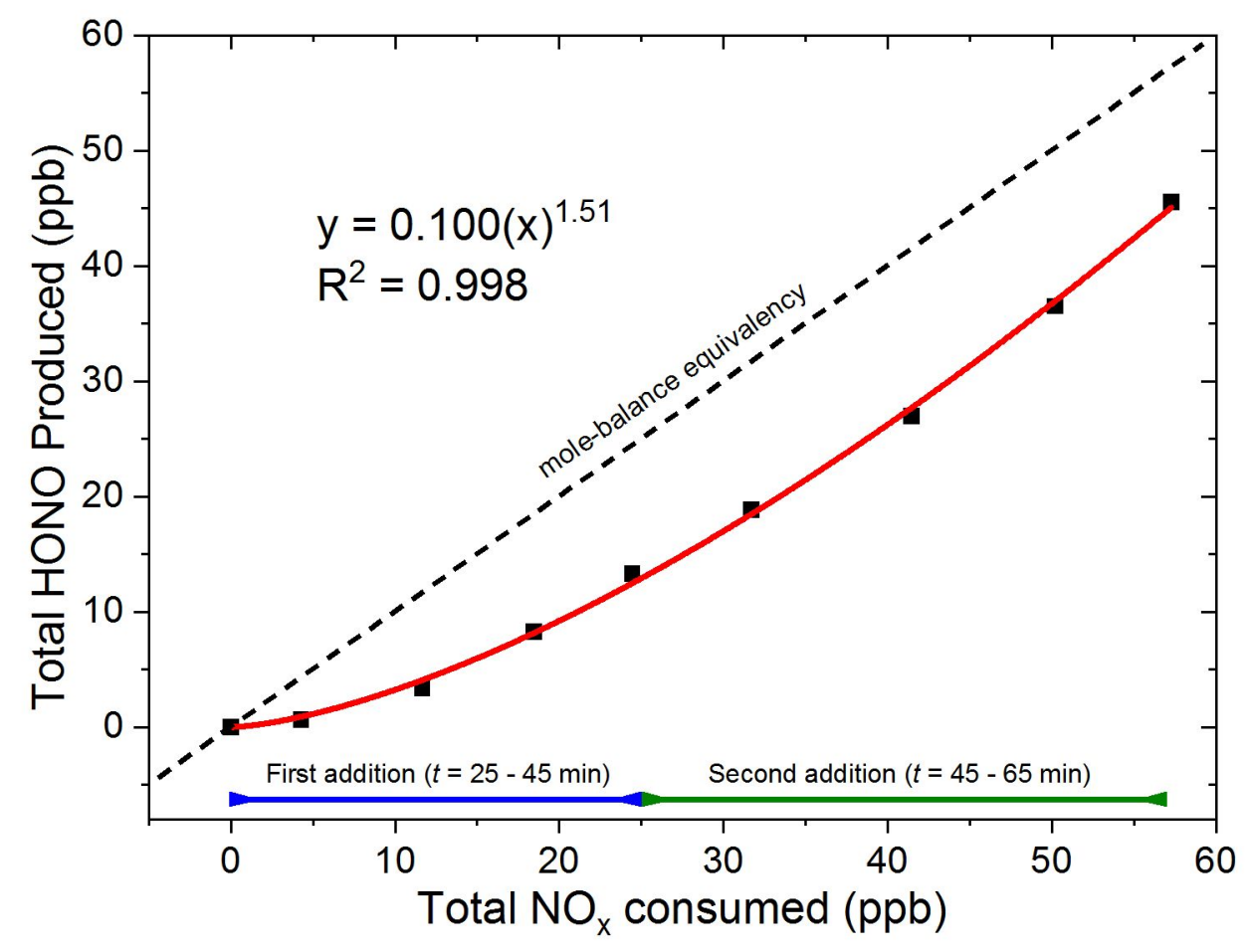

Figure S6. Comparison of $\mathrm{HONO}_{(\mathrm{g})}$ formation rates to $\mathrm{NO}_{\mathrm{x}(\mathrm{g})}$ consumption rates during DAOM

358 titration experiment. The first data-point $(0,0)$ corresponds to $t=25 \mathrm{~min}$ in Figure 2. The $\mathrm{NO}_{2}$-to-

359 HONO conversion rate increases throughout irradiation of the experiment, with a complete 1:1

360 conversion reached at $t=33 \mathrm{~min}$. 


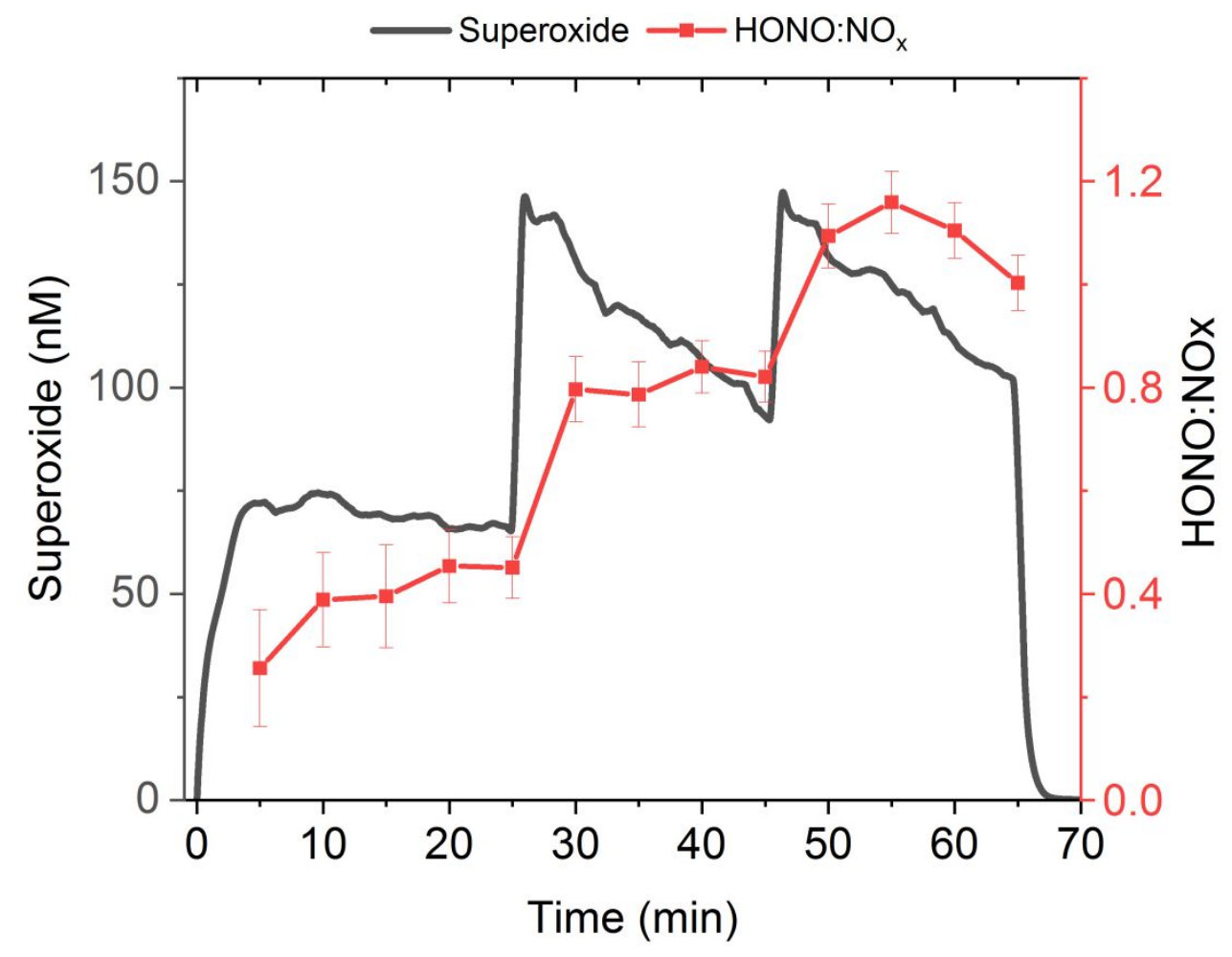

370 Figure S7. Comparison of superoxide concentrations (black) with overall ratio of HONO

371 to $\mathrm{NO}_{\mathrm{x}}$ (red squares) during organic matter spike experiment. Error bars represent 372 appropriate error propagation of all measured $\mathrm{NO}_{\mathrm{y}}$ species. 
A

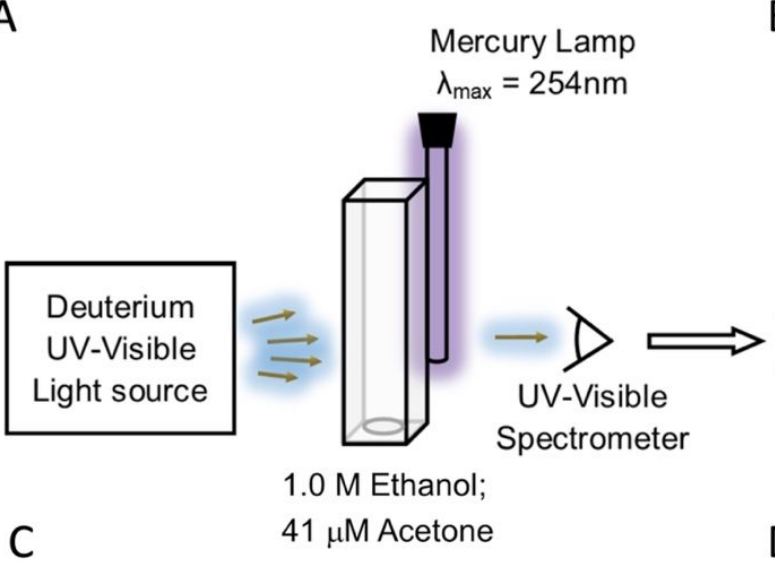

B Quantification by 2nd order kinetic model

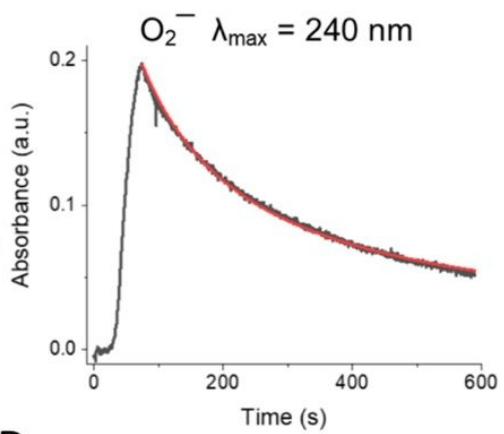

D
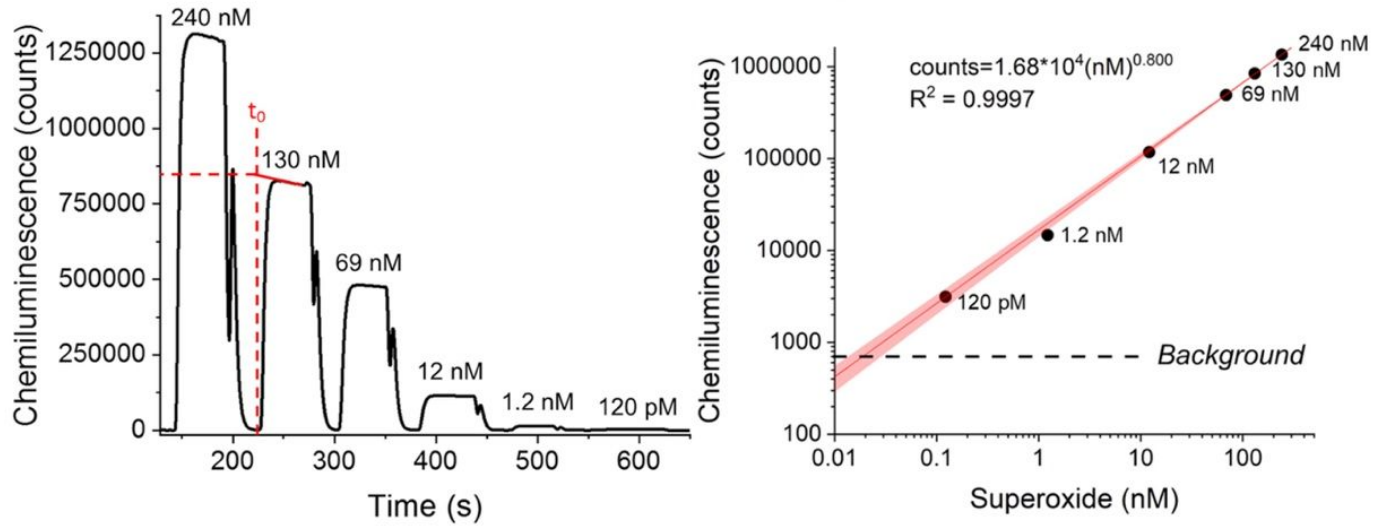

375 Figure S8. Flow injection analyzer calibration schematic. (A) Superoxide is produced

376 photochemically by irradiation of a pH 12 solution of $1 \mathrm{M}$ ethanol and $41 \mu \mathrm{M}$ acetone. (B) This

377 stock solution is quantitated by a second order kinetic model according to Dimento. ${ }^{5}$ (C) An aliquot

378 of known concentration is serially diluted to several concentrations to span 4 orders of magnitude.

379 Chemiluminescence determined at time of aliquot addition $\left(t_{0}\right)$. (D) A log-log calibration curve is

380 prepared by determining the theoretical chemiluminescence at the exact time of $\mathrm{O}_{2}^{-}$solution

381 preparation. 


\section{Supplementary References}

384

385

386

387

388

389

390

391

392

393

394

395

396

397

398

399

400

401

402

403

404

405

406

407

408

409

410

411

412

(1) Rose, A. L.; Moffett, J. W.; Waite, T. D. Determination of superoxide in seawater using 2methyl-6-(4-methoxyphenyl)- 3,7-dihydroimidazo[1,2-a]pyrazin-3(7H)-one chemiluminescence. Anal. Chem. 2008, 80 (4), 1215-1227.

(2) Heland, J.; Kleffmann, J.; Kurtenbach, R.; Wiesen, P. A new instrument to measure gaseous nitrous acid (HONO) in the atmosphere. Environ. Sci. Technol. 2001, 35 (15), 3207-3212.

(3) Kleffmann, J.; Wiesen, P. Technical Note: Quantification of interferences of wet chemical HONO LOPAP measurements under simulated polar conditions. Atmos. Chem. Phys. 2008, 8 (22), 6813-6822.

(4) Galbavy, E. S.; Ram, K.; Anastasio, C. 2-Nitrobenzaldehyde as a chemical actinometer for solution and ice photochemistry. J. Photochem. Photobiol. A Chem. 2010, 209 (2-3), 186192.

(5) Dimento, B. A method for the photochemical production of superoxide radicals in aqueous acetone-ethanol solutions, and the simultaneous chemiluminescent detection of superoxide and hydrogen peroxide, Colby College, 2010.

(6) Bielski, B. H. J.; Cabelli, D. E.; Arudi, R. L.; Ross, A. B. Reactivity of HO2/O2- radicals in aqueous solution. J. Phys. Chem. Ref. Data 1985, 14 (4), 1041-1100.

(7) Tekle-Röttering, A.; Lim, S.; Reisz, E.; Lutze, H. V.; Abdighahroudi, M. S.; Willach, S.; Schmidt, W.; Tentscher, P. R.; Rentsch, D.; McArdell, C. S.; Schmidt, T. C.; Von Gunten, U. Reactions of pyrrole, imidazole, and pyrazole with ozone: Kinetics and mechanisms. Environ. Sci. Water Res. Technol. 2020, 6 (4), 976-992.

(8) Scharko, N. K.; Berke, A. E.; Raff, J. D. Release of nitrous acid and nitrogen dioxide from nitrate photolysis in acidic aqueous solutions. Environ. Sci. Technol. 2014, 48 (20), 11991-12001.

(9) Reeser, D. I.; Kwamena, N. O. A.; Donaldson, D. J. Effect of organic coatings on gasphase nitrogen dioxide production from aqueous nitrate photolysis. J. Phys. Chem. C 2013, 117 (43), 22260-22267.

(10) Goldstein, S.; Lind, J.; Merenyi, G. Reaction of Organic Peroxyl Radicals with NO2 and NO in Aqueous Solution: Intermediacy of Organic Peroxynitrate and Peroxynitrite 
Species. J. Phys. Chem. A 2004, 108 (10), 1719-1725.

(11) Karpel Vel Leitner, N.; Dore, M. Hydroxyl radical induced decomposition of aliphatic acids in oxygenated and deoxygenated aqueous solutions. J. Photochem. Photobiol. A Chem. 1996, 99 (2-3), 137-143.

(12) Bothe, E.; Schuchmann, M. N.; Schulte-Frohlinde, D.; Sonntag, C. von. HO2 elimination from $\alpha$-hydroxyalkylperoxyl radicals in aqueous solution. Photochem. Photobiol. 1978, 28 (4-5), 639-643.

(13) Gross, S.; Bertram, A. K. Products and kinetics of the reactions of an alkane monolayer and a terminal alkene monolayer with NO3 radicals. J. Geophys. Res. Atmos. 2009, 114 (2), 1-14.

(14) Goldstein, S.; Czapski, G. The reaction of $\mathrm{NO} \cdot$ with $\mathrm{O} 2 \cdot-$ and $\mathrm{HO} 2 \cdot-$ : A pulse radiolysis study. Free Radic. Biol. Med. 1995, 19 (4), 505-510.

(15) Løgager, T.; Sehested, K. Formation and decay of peroxynitric acid: a pulse radiolysis study. J. Phys. Chem. 1993, 97 (39), 10047-10052.

(16) Goldstein, S.; Lind, J.; Merényi, G. Chemistry of peroxynitrites as compared to peroxynitrates. Chem. Rev. 2005, 105 (6), 2457-2470.

(17) Padmaja, S.; Huie, R. E. The reaction of nitric oxide with organic peroxyl radicals. Biochemical and Biophysical Research Communications. 1993, pp 539-544.

(18) Reed, C.; Brumby, C. A.; Crilley, L. R.; Kramer, L. J.; Bloss, W. J.; Seakins, P. W.; Lee, J. D.; Carpenter, L. J. HONO measurement by differential photolysis. Atmos. Meas. Tech. 2016, 2483-2495.

(19) Thomas, J. K. Rates of reaction of the hydroxyl radical. Trans. Faraday Soc. 1965, 61, $702-707$.

(20) Fisher, M. M.; Hamill, W. H. Electronic processes in pulse-irradiated aqueous and alcoholic systems. J. Phys. Chem. 1973, 77 (2), 171-177.

(21) Scholes, G.; Willson, R. L. $\gamma$-Radiolysis of aqueous thymine solutions. Determination of relative reaction rates of OH radicals. Trans. Faraday Soc. 1967, 63, 2983-2993.

(22) Logan, S. R. Redox reactions of organic radicals with ferrocene/ferricenium species in aqueous solution. Part 1. Radicals derived from carboxylic acids. J. Chem. Soc. Perkin Trans. 2 1989, No. 7, 751-754.

(23) Anbar, M.; Meyerstein, D.; Neta, P. Reactivity of aliphatic compounds towards hydroxyl 
radicals. J. Chem. Soc. B Phys. Org. 1966, 742-747.

(24) Buxton, G. V; Greenstock, C. L.; Helman, W. P.; Ross, A. B. Critical review of rate constants for reactions of hydrated electrons, hydrogen atoms and hydroxyl radicals (. $\mathrm{OH} / \cdot \mathrm{O}-$ in aqueous solution. J. Phys. Chem. Ref. data 1988, 17 (2), 513-886.

(26) Burkholder, J. B.; Sander, S. P.; Abbatt, J. P. D.; Barker, J. R.; Huie, R. E.; Kolb, C. E.; Kurylo, M. J.; Orkin, V. L.; Wilmouth, D. M.; Wine, P. H. Chemical kinetics and photochemical data for use in atmospheric studies: evaluation number 18; Pasadena, CA: Jenkin, M. E.; Rossi, M. J.; Troe, J. Evaluated kinetic and photochemical data for atmospheric chemistry: Volume I - gas phase reactions of $\mathrm{O}_{\mathrm{x}}, \mathrm{HO}_{\mathrm{x}}, \mathrm{NO}_{\mathrm{x}}$ and $\mathrm{SO}_{\mathrm{x}}$ species. Atmos. Chem. Phys. 2004, 4 (6), 1461-1738.

Jet Propulsion Laboratory, National Aeronautics and Space ..., 2015.

27) Tyndall, G. S.; Orlando, J. J.; Calvert, J. G. Upper limit for the Rate Coefficient for the Reaction HO2 + NO2 $\rightarrow$ HONO + O2. Environ. Sci. Technol. 1995, 29 (1), 202-206. 